\title{
Macroinfaunal communities of the Santa Maria Basin on the California outer continental shelf and slope
}

\author{
Jeffrey Hyland ${ }^{1}$, Ellen Baptiste ${ }^{2}$, James Campbell ${ }^{3}$, Janet Kennedy ${ }^{2}$, \\ Roy Kropp ${ }^{2}$, Susan Williams ${ }^{4}$ \\ ${ }^{1}$ Marine Science Institute, University of California, Santa Barbara, California 93106, USA \\ ${ }^{2}$ Battelle Ocean Sciences, 397 Washington Street, Duxbury, Massachusetts 02332, USA \\ ${ }^{3}$ Marine Research Specialists, 3639 E. Harbor Blvd., Ventura, California 93001, USA \\ ${ }^{4} 392$ South Catalina Street, Ventura, California 93001, USA
}

\begin{abstract}
We present results of a 2.5 yr survey of the macroinfauna along the California coast north of Point Conception, between Purisima Point and Point San Luis (USA), at outer-shelf and slope depths of 90 to $565 \mathrm{~m}$. The study area, representing the southern offshore portion of the Santa Maria Basin, is an oceanographically complex and productive region, which is also believed to contain major petroleum deposits. This area supports a highly diverse and abundant macroinfauna, represented mostly by crustaceans $(34 \%)$, polychaetes $(31 \%)$, and molluscs $(18 \%)$. Average numbers of species and densities (up to $1510.1 \mathrm{~m}^{-2}$ and $28826 \mathrm{~m}^{-2}$, respectively, at water depths under $200 \mathrm{~m}$ ) equal those reported for other productive regions, such as Georges Bank and the North Sea. Spatial differences in the composition of these assemblages are related foremost to water depth in addition to variations in sedimentary and other depth-associated physical variables. Patterns of decreasing abundances and diversity with increasing depth appear to be due partly to a bottom dissolved-oxygen gradient $\left(3.1 \mathrm{ml} \mathrm{l}^{-1}\right.$ at $90 \mathrm{~m}$ to $0.6 \mathrm{ml} \mathrm{l}^{-1}$ at $565 \mathrm{~m}$ ), which includes values at the low end that are below the oxygen tolerance of many benthic invertebrates. Variations in the percentage of sand explain further differences that segregate some stations of comparable depth and oxygen levels. Macrofaunal variables also show significant temporal fluctuations, although distinct seasonal cycles are hard to detect and are not repeated throughout all sampling years and stations. The occurrence of density peaks in the spring during one or more sampling years at several of the stations, however, suggests a benthic response to upwelling events, which are known to contribute to increases in new primary production and ultimately to increased energy supplies to the benthos. Results of this study provide a basis for beginning to understand natural sources of variation in the benthos of the region. which should be considered in efforts to assess potential impacts of future oil development.
\end{abstract}

\section{INTRODUCTION}

The California outer continental shelf and slope just north of Point Conception (USA) is an oceanographically complex and productive region characterized, for example, by strong coastal upwelling (Brink et al. 1984. Kinney et al. 1990) and associated increases in new primary production (Dugdale \& Wilkerson 1989). It is also an area believed to contain major new reservoirs of offshore petroleum (Rintoul 1985). The benthic ecology of this region has been poorly understood and was virtually unstudied until these recent oil discoveries.
The present study was performed as a component of a larger interdisciplinary monitoring program (Hyland et al. 1990) designed to assess potential long-term cumulative impacts of offshore oil development in the southern part of Santa Maria Basin, a geologic feature encompassing the bulk of the California continental margin between Point Conception and Monterey Bay. This is one of few studies to provide a comprehensive examination of spatial and temporal variability of offshore infauna along the California coast north of Point Conception. Previous studies of the macroinfauna of this area have been limited largely to site-specific surveys conducted around individual offshore platform 
sites (unpubl. reports prepared for oil companies: Dames \& Moore 1983, Engineering-Science 1984, Nekton 1983, 1984, McClelland Engineers 1985) or to broader-based reconnaissance surveys conducted at single points in time (SAIC 1986, Lissner 1989, Cimberg \& Smith in press). Thompson et al. (1985) also examined macroinfaunal distributions in relation to the oxygen minimum zone at sites further north, offshore of Pt. Sur, California.

In the present paper, we present results of basic research on the structure and dynamics of the macroinfauna and on the relationships of the fauna to other natural environmental variables. Results are based on samples collected at 8 time intervals over a $2.5 \mathrm{yr}$ period. The purposes of our analysis are to describe the faunal assemblages; examine their spatial and temporal patterns; and relate the faunal distributions to other environmental factors that may be of importance in controlling the observed patterns. Results reflect baseline conditions relative to oil-production in the immediate sampling area. A companion study of meiobenthic communities, sampled along with the macrofauna, is reported elsewhere by Montagna (in press).

\section{METHODS}

Field collections and sample processing. The primary data base for this paper was derived from the analysis of 230 sediment samples of $0.1 \mathrm{~m}^{2}$ collected along 3 cross-shelf transects of 3 stations each (encompassing depths of 90 to $410 \mathrm{~m}$ ) and from an additional station, R-7, located ca $50 \mathrm{~km}$ west of Point Sal (at a depth of $565 \mathrm{~m}$ ) in a sea valley adjacent to the Santa Lucia Bank (Fig. 1). Typically, 3 replicate samples were collected from each of the 10 stations on 8 sampling occasions: October 1986, January 1987. May 1987. October 1987, January 1988, May 1988, October 1988, and May 1989. However, Stations R-8 and R-9 were not sampled in October 1986, and Station R-7 was not sampled in May 1988. Also, only 2 replicates were obtained at Station R-3 in May 1988. An additional set of 114 samples were collected on several of the sampling occasions from a closely spaced array of 18 stations centered around Station PJ-1, the proposed site for an offshore oil and gas production platform (Platform Julius). Data from these latter samples are used here in the description of overall taxonomic composition but have been excluded from remaining analyses

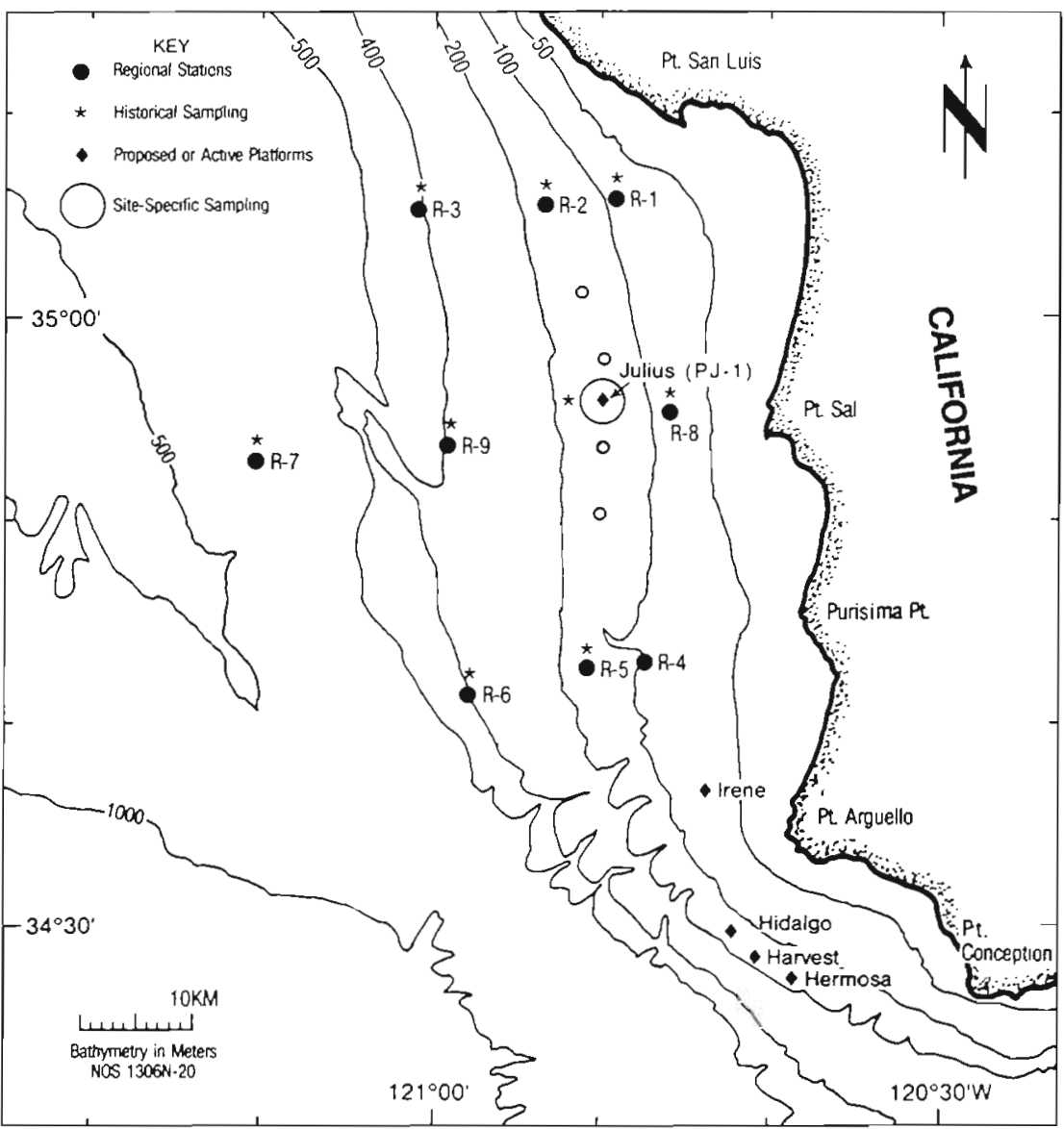

Fig. 1. Study area and station design Historical sampling sites (asterisks) refer to coinciding sites sampled by SAIC (1986) 
of regional faunal patterns and relationships of the fauna to other environmental variables.

Samples were obtained with a Hessler-Sandia 0.25 $\mathrm{m}^{2}$ box corer partitioned into 25 individual $0.01 \mathrm{~m}^{2}$ subcores. From each sample, 10 subcores were removed from the corer and prepared for macroinfaunal analysis. Remaining subcores were used for analysis of meiofauna, hydrocarbons, trace metals, sediment grain-size, total organic carbon, sediment shear strength, redox conditions, distribution of mineral types, radioisotope profiles, and bioturbation processes. Near-bottom hydrocasts were also taken at or near each station to provide measurements of dissolved oxygen, salinity, $\mathrm{pH}$, and temperature. A subset of these variables was selected to examine possible relationships with the macroinfaunal data.

The upper $10 \mathrm{~cm}$ of each subcore obtained for macroinfaunal analysis were live-sieved through a 0.3 $\mathrm{mm}$ screen with filtered seawater. All 10 subcores from the same box core were recombined during this sieving process, yielding a total surface area of $0.1 \mathrm{~m}^{2}$ per replicate sample. Material retained on the screen was preserved with ca $10 \%$ buffered formalin. Once samples were returned to the laboratory, they were resieved on a nest of $0.5 \mathrm{~mm}$ and $0.3 \mathrm{~mm}$ screens and transferred to $70 \%$ ethanol. The $0.5 \mathrm{~mm}$ fraction was used for analysis of macroinfauna; the $0.3 \mathrm{~mm}$ fraction was archived.

Samples were sorted in the laboratory under dissecting microscopes and were stained with a saturated solution of rose bengal, for 4 to $24 \mathrm{~h}$, to facilitate the sorting process. All individuals were enumerated and identified to the species level wherever possible. Colonial forms and temporary members of the benthos were excluded from all data analyses. Unidentifiable juveniles and damaged specimens were excluded from most data analyses except estimates of density. A quantitative species list can be obtained from the senior author.

Data analyses. Data were analyzed by a combination of the following methods: inspection of species lists to examine taxonomic composition and dominant species (10 most abundant species by station); calculation of species diversity and other community characteristics: numerical classification to identify patterns of faunal similarity; analysis of variance (ANOVA) to test for the significance of spatial and temporal differences; and multiple discriminant analysis to examine relationships between the macroinfauna and other environmental variables. Procedures provided in SAS (1985) were used to perform ANOVA (PROC GLM) and multiple discriminant analysis (PROC CANDISC). A customized package of statistical subroutines was used for the diversity measures and numerical classification.
Measures of diversity and other community characteristics consisted of numbers of individuals and of species, $S$; the Shannon information function, $H^{\prime}$ (Shannon $\&$ Weaver 1949); and the associated evenness component, $J^{\prime}$ (Pielou 1966). Base 2 logarithms were used to calculate $H^{\prime}$.

Normal (Q-mode) numerical classification (Boesch 1977) was performed on data transformed to $\log _{10}$ $(x+1)$. Group-average sorting (= unweighted pairgroup method; Sneath \& Sokal 1973) was used as the clustering method and Bray-Curtis similarity (Bray \& Curtis 1957) was used as the resemblance measure. Results are expressed here in the form of dendrograms in which samples have been ordered into groups of increasingly greater similarity based on resemblances of component-species abundances.

A sequence of 3-way, 2-way, and 1-way ANOVA models was used to test for the significance of main effects of depth, time, transect location, and their interactions on the following response variables: number of species, density of total fauna, and densities of selected dominant species. Student-Newman-Keuls multiple range tests were used in conjunction with ANOVA to locate where significant differences exist between the various levels of each class variable. Data were transformed to $\log _{10}(x+1)$ An alpha value of 0.05 was selected as the significance level.

As recommended by Green \& Vascotto (1978), multiple (canonical) discriminant analysis was used to determine whether the group separation derived by numerical classification of the macroinfaunal species data can be explained by other measured environmental variables. The other variables used are sediment organic matter (total organic carbon, expressed as \% dry wt), mean particle size (in phi units), sorting coefficient (quartile deviation, in phi units). \% sand, $\%$ silt, \% clay, near-bottom dissolved oxygen $\left(\mathrm{ml} \mathrm{l}^{-1}\right)$, density of all meiofaunal members (size range $=0.063$ to $0.50 \mathrm{~mm}$ ), density of protozoan meiofauna, and density of metazoan meiofauna. Physical variables and meiofaunal variables were tested separately. All data were transformed to $\log _{10}(x+1)$, unless already in log form (e.g. variables expressed in phi units). The discriminant analysis was used to derive a reduced set of discriminant functions that best describe the separation of the predeclared station groups based on data represented by the different environmental variables. Total structure coefficients, which are the correlations between the original variables and the discriminant scores on each function, served as a measure of the relative contribution of each variable to group separation. Station groups were then plotted in the reduced discriminant space and interpreted visually in light of those variables that accounted for the majority of the separation. 
Table 1. Summary of major taxonomic groups

\begin{tabular}{|c|c|c|}
\hline $\begin{array}{l}\text { Taxonomic } \\
\text { group }\end{array}$ & $\begin{array}{c}\text { Number } \\
\text { identifiable } \\
\text { taxa }\end{array}$ & $\begin{array}{c}\% \text { Total } \\
\text { identifiable } \\
\text { taxa }\end{array}$ \\
\hline Phylum Porifera ${ }^{a}$ & 1 & 0.1 \\
\hline \multicolumn{3}{|l|}{ Phylum Cnidaria } \\
\hline Class Hydrozoa & 20 & 2.3 \\
\hline Class Anthozoa & 37 & 4.2 \\
\hline Phylum Platyhelminthes & 1 & 0.1 \\
\hline Phylum Nemertina & 16 & 1.8 \\
\hline Phylum Priapulida & 1 & 0.1 \\
\hline Phylum Sipuncula & 5 & 0.6 \\
\hline \multicolumn{3}{|l|}{ Phylum Mollusca } \\
\hline Class Gastropoda & 85 & 9.6 \\
\hline Class Aplacophora & 17 & 1.9 \\
\hline Class Bivalvia & 67 & 7.6 \\
\hline Class Scaphopoda & 10 & 1.1 \\
\hline Phylum Echiura & 5 & 0.6 \\
\hline \multicolumn{3}{|l|}{ Phylum Annelida } \\
\hline Class Polychaeta & 278 & 31.4 \\
\hline Class Oligochaeta & 6 & 0.7 \\
\hline \multicolumn{3}{|l|}{ Phylum Arthropoda } \\
\hline Class Pycnogonida & 5 & 0.6 \\
\hline \multicolumn{3}{|l|}{ Class Crustacea } \\
\hline Subclass Ostracoda & 31 & 3.5 \\
\hline Subclass Cirripedia ${ }^{a}$ & 1 & 0.1 \\
\hline \multicolumn{3}{|l|}{ Subclass Malacostraca } \\
\hline \multicolumn{3}{|l|}{ SupOrd Peracarida } \\
\hline Mysidacea & 13 & 1.5 \\
\hline Cumacea & 52 & 5.9 \\
\hline Tanaidacea & 18 & 2.0 \\
\hline Isopoda & 18 & 2.0 \\
\hline Amphipoda & 153 & 17.3 \\
\hline \multicolumn{3}{|l|}{ SupOrd Eucarida } \\
\hline Euphausiacea ${ }^{d}$ & 8 & 0.9 \\
\hline Decapoda $^{d}$ & 10 & 1.1 \\
\hline Phylum Bryozoad & 4 & 0.5 \\
\hline Phylum Brachiopoda & 1 & 0.1 \\
\hline \multicolumn{3}{|l|}{ Phylum Echinodermata } \\
\hline \multicolumn{3}{|l|}{ Class Stelleroidea } \\
\hline Asteroidea & 2 & 0.2 \\
\hline Ophiuroidea & 12 & 1.4 \\
\hline Class Echinoidea & 4 & 0.5 \\
\hline Class Holothuroidea & 3 & 0.3 \\
\hline Phylum Hemichordata & 1 & 0.1 \\
\hline \multicolumn{3}{|l|}{ Phylum Chordata } \\
\hline Subphy. Urochordata & 1 & 0.1 \\
\hline Total & 886 & 100 \\
\hline
\end{tabular}

\section{RESULTS}

\section{Taxonomic and zoogeographic composition}

A total of 886 species representing 15 phyla (Table 1) have been identified among 444989 specimens encountered in all samples (344 cores). Most (551) have been identified to species level. The remaining
335 species are recognized as distinct taxa but have been given provisional codes because they are either new to science or not known to the participating taxonomists. The actual number of species encountered is probably much higher considering the presence of an additional 339 unidentifiable taxa represented by indeterminate juveniles or fragments of specimens (not included in Table 1). The largest percentages of identifiable taxa are represented by crustaceans (34\%, mostly peracarida) and polychaetes $(31 \%)$. Gastropods $(10 \%)$ and bivalves $(8 \%)$ contribute the next highest percentages of species. Together these 4 classes account for $83 \%$ of all taxa.

The study area is located at the boundary separating 2 major zoogeographic provinces, the Oregonian and Californian, as defined by Valentine (1966). An examination of the latitudinal ranges of ca $75 \%$ of the polychaetes, crustaceans (except cumaceans), and molluscs encountered in the present study revealed that the majority (69\%) have northern affinities, either as members of the Oregonian Province (32\%) or as wideranging northern species $(37 \%)$. Species with primarily southern affinities comprise $26 \%$ of the fauna, most $(22 \%)$ being members of the California Province and the remaining ones having wide-ranging southern distributions. Five percent of the taxa examined appear to be endemic to the study area.

\section{Numerical classification}

Numerical classification of samples combined over all replicates and cruises from the various regional stations defines 4 major groups reflecting depthrelated differences in macroinfaunal species composition (Fig. 2). These groups consist of all outer-shelf stations at depths of about $90 \mathrm{~m}(\mathrm{R}-8, \mathrm{R}-1$, and $\mathrm{R}-4=$ Cluster Group 1); all upper-slope stations at depths of 145 to $1.61 \mathrm{~m}$ (PJ-1, R-2, and R-5 = Cluster Group 2); all mid-slope stations at depths of about $410 \mathrm{~m}(\mathrm{R}-3, \mathrm{R}-9$, and R-6 = Cluster Group 3); and the sea-valley station $\mathrm{R}-7$ at $565 \mathrm{~m}$ (Cluster Group 4). These variations with depth appear to be related to the near-bottom oxygen gradient (see below). Additional environmental factors (e.g. \% sand) may explain the remaining differences that segregate Stations R-5 (Group 2B) and R-6 (Group $3 B$ ) along the southern transect from corresponding stations of comparable depth.

\section{Dominant species}

Dominant ( 10 most abundant) species and estimates of their abundances by station are presented in Table 2. These species account for more than $50 \%$ of 
Fig. 2. Dendrogram resulting from clustering of stations, using group-average sorting, and Bray-Curtis similarity. Samples within each station are combined over all replicates and cruises (except Oct 1986 and May 1988 cruises are deleted to create equal sample sizes among stations). Station pairs with similarities $\geq 0.650$ are placed within the same cluster group

\section{Cluster groups}

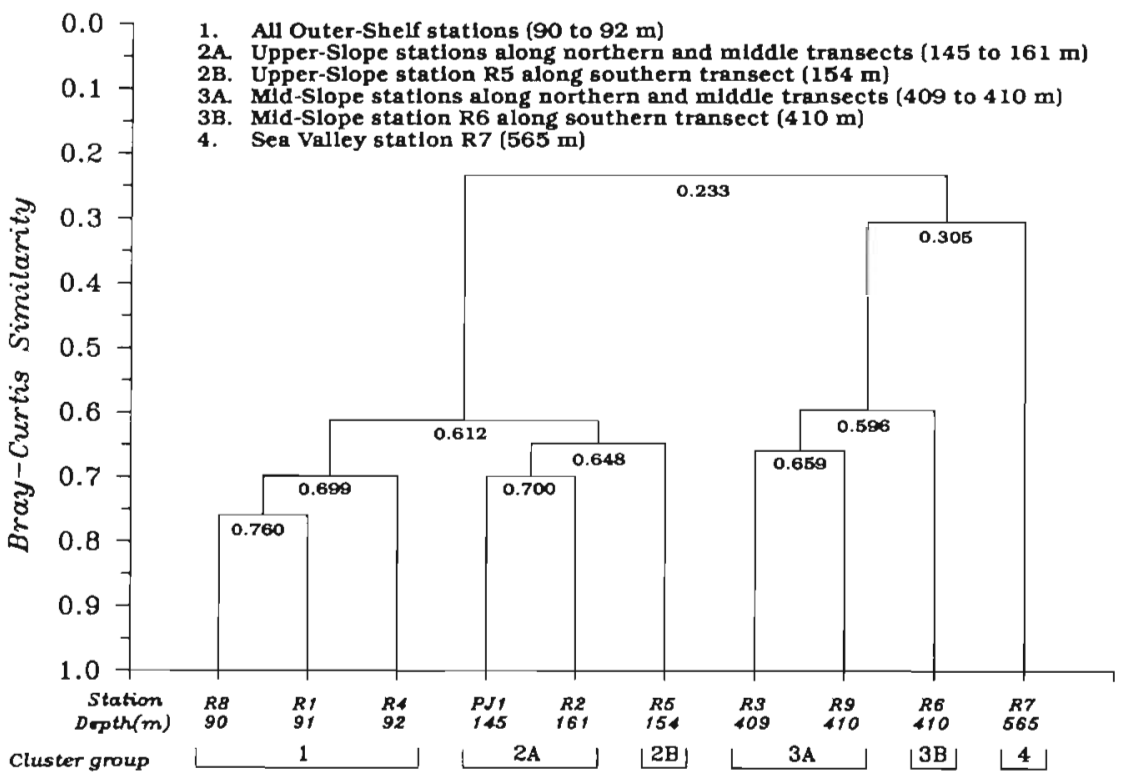

the cumulative percent abundance of all species at a given station. The data are averaged over all sampling times and arranged to allow visual comparisons between depths and transect locations.

Among outer-shelf and upper-slope stations (90 to $161 \mathrm{~m}$; Cluster Groups 1 and 2) the most persistent and strongly ranked dominants are the 2 polychaetes Mediomastus ambiseta and Chloeia pinnata. Other important co-dominants are the polychaetes Minuspio (Prionospio) lighti, Levinsenia gracilis and Pholoe glabra. Ophiuroids (Amphiodia urtica) are also characteristic of the shallowest stations (90 to $92 \mathrm{~m}$ ), and several dominant species of crustaceans ( 3 amphipods, 1 tanaid, and 1 isopod) are increasingly abundant among the southern stations within this depth range. The Amphiodia influence at the shallower depths suggests some resemblance of our outer-shelf fauna to the Amphiodia-Cardita association described by Jones (1969) for shelf sites south of Point Conception. However, in the present study, Amphiodia is not the highest ranked dominant and, while Cyclocardia ventricosa ( $=$ Cardita) is present at moderately low densities, the clams Parvilucina tenuisculpta and Acila castrenis are ranked as the dominant molluscs. The outer-shelf to upper-slope stations in the present study also bear some resemblance to the 'shelf' (Site Group 1) and 'upper-slope' (Site Groups 4 and 6) stations described in the 'Phase I Reconnaissance Study' conducted previously in the same study area (SAIC 1986). For example, species such as Amphiodia urtica; the polychaetes Spiophanes berkeleyorum, S. missionensis and Chloeia pinnata; and the clam Acila castrensis are mentioned as co-dominants at these depths in both studies. However, a striking difference is the complete absence of Mediomastus ambiseta in the earlier Phase I study.

At the deeper mid-slope stations $(410 \mathrm{~m}$; Cluster Group 3), Mediomastus ambiseta drops out as a dominant and the polychaetes Chloeia pinnata and Nephtys cornuta become the 2 most persistent and strongly ranked dominants. These deeper stations are also characterized by the absence of Minuspio lighti and by increasing dominance of several other polychaete species (Maldane sarsi, Chaetozone nr. setosa, Minuspio sp. A, Cossura rostrata and Cossura candida); oligochaetes (Tectidrilus diversus); crustaceans (including the cumaceans Leucon magnadentata, Eudorella pacifica, and Eudorella sp. 1 and the amphipods Pseudharpinia excavata and Harpiniopsis fulgens); and 2 species of molluscs (the scaphopod Cadulus californica and the bivalve Huxleyia munita). SAIC (1986) also describes a 'mid-slope' assemblage (Site Group 8) centered on approximately the $400 \mathrm{~m}$ isobath and containing Chloeia pinnata and Maldane sarsi as co-subdominants. However, unlike the present study, their study did not mention Nephtys cornuta as a dominant and listed the snail Amphissa bicolor as the highest ranked dominant at this depth.

The deepest station (R-7; Cluster Group 4) is characterized by an overwhelming dominance of the phoxocephalid amphipod Harpiniopsis epistomata, which accounts for over $50 \%$ of the total faunal abundance. Station R-7 is also characterized by the absence of Mediomastus ambiseta, a decline in the relative dominance of Chloeia pinnata, and an increase in the dominance of Maldane sarsi. This 


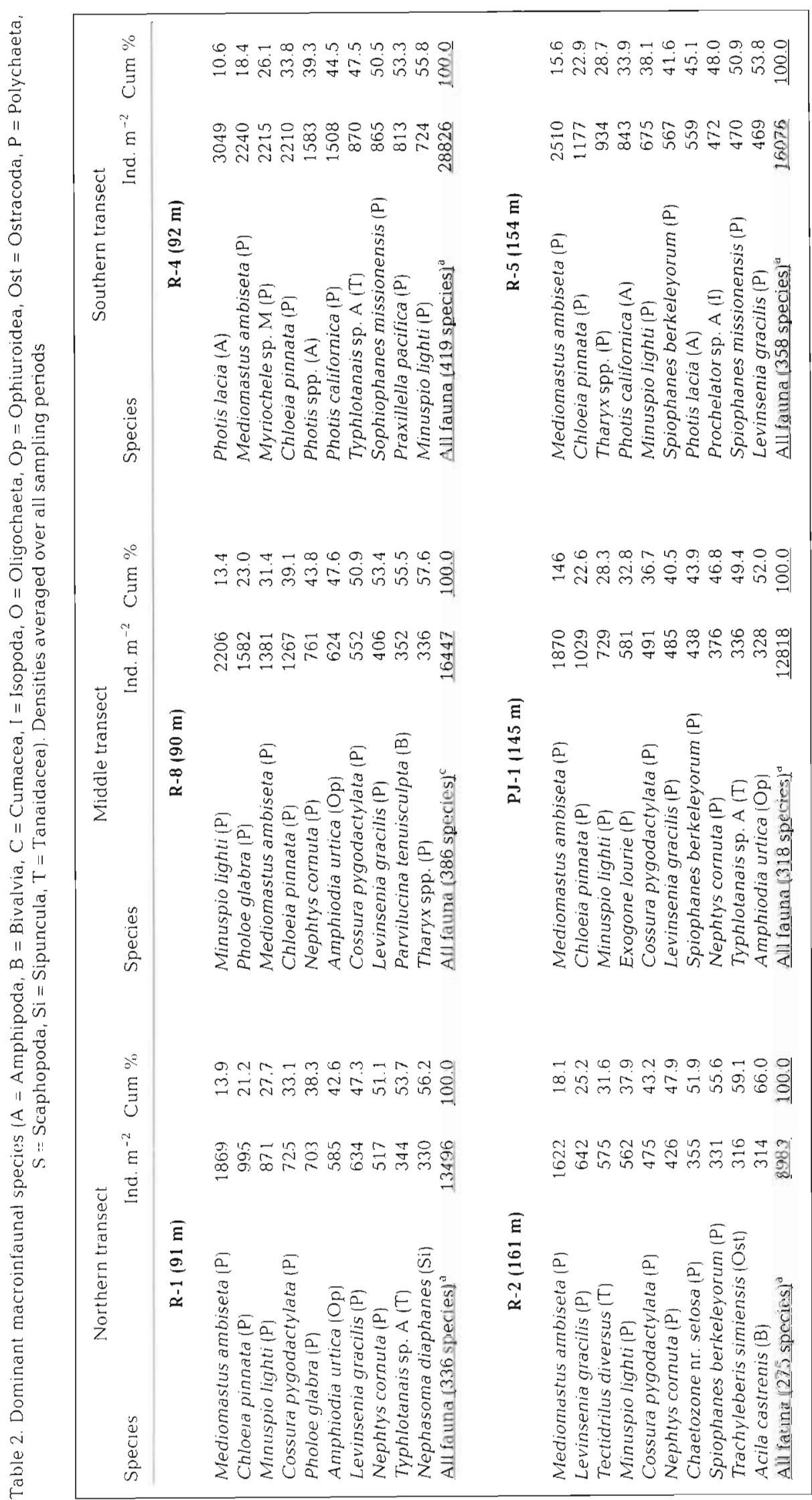




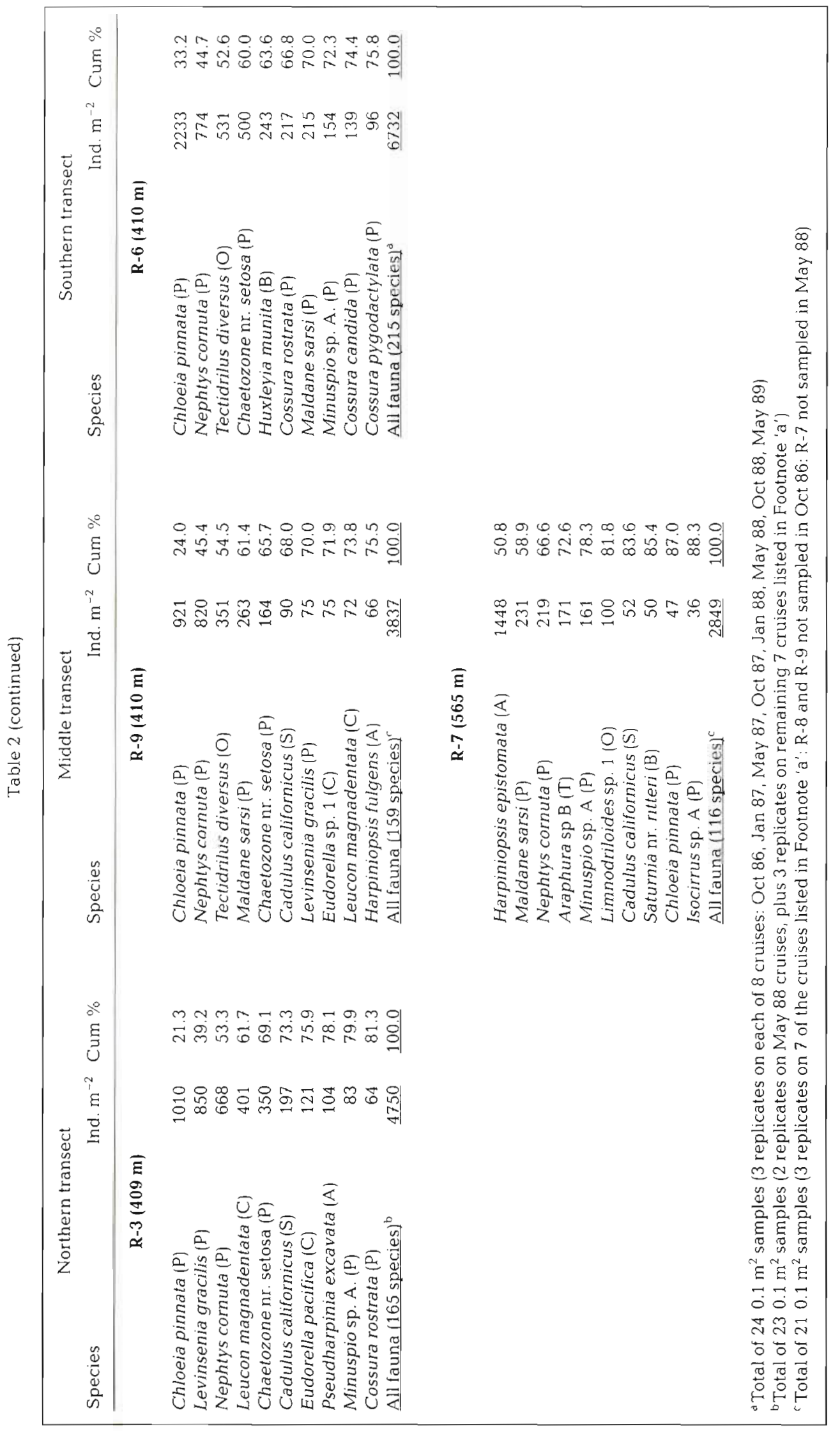


Table 3. Summary of community variables (all replicates and cruises combined within stations)

\begin{tabular}{|c|c|c|c|c|c|c|c|c|}
\hline Station & Transect & $\begin{array}{l}\text { Depth } \\
\text { (m) }\end{array}$ & Ind. $\mathrm{m}^{-2}$ & $\left(\text { Ind } \mathrm{m}^{-2}\right)^{d}$ & $\begin{array}{c}\text { Av. } S \\
0.1 \mathrm{~m}^{-2}\end{array}$ & Total S & $H^{\prime}$ & $J^{\prime}$ \\
\hline R-1 & North & 91 & 13496 & 17100 & 121 & 336 & 5618 & 0.669 \\
\hline R-2 & North & 161 & 8983 & 9864 & 85 & 275 & 5210 & 0.643 \\
\hline $\mathrm{R}-3$ & North & 409 & 4750 & 4836 & 46 & 165 & 4108 & 0.557 \\
\hline$R-8$ & Mid & 90 & 16447 & 19214 & 141 & 386 & 5577 & 0.649 \\
\hline $\mathrm{PJ}-1$ & Mid & 145 & 12818 & 14840 & 108 & 318 & 5570 & 0.670 \\
\hline R-9 & Mid & 410 & 3837 & 3996 & 45 & 159 & 4222 & 0.577 \\
\hline $\mathrm{R}-7$ & Mid & 565 & 2849 & 2964 & 26 & 116 & 3123 & 0.455 \\
\hline $\mathrm{R}-4$ & South & 92 & 28826 & 30771 & 151 & 419 & 5631 & 0.646 \\
\hline R-5 & South & 154 & 16076 & 16885 & 123 & 358 & 5564 & 0.656 \\
\hline $\mathrm{R}-6$ & South & 410 & 6732 & 7063 & 61 & 215 & 4229 & 0.546 \\
\hline
\end{tabular}

station corresponds to the deep-slope and Santa Lucia Valley group (Site Group 10) of the Phase I study (SAIC 1986), although both Harpiniopsis epistomata and Maldane sarsi are described in that study as being co-dominants of a separate Santa Lucia Bank and Arguello Canyon group (Site Group 11).

\section{Diversity and related community characteristics}

A summary of diversity and other community characteristics for the various regional stations is given in Table 3. There are distinct depth-related trends in these variables along all 3 transects. Densities of total fauna, numbers of species, and species diversity $\left(H^{\prime}\right)$ all decrease as a function of increasing depth. The evenness component $\left(J^{\prime}\right)$ shows similar differences, with the lowest values associated with the deepest stations, although the pattern is less clear among some of the shallower stations. There is also a general trend of increasing numbers of individuals and species from the northern to the southern transect.

\section{Statistical analysis of spatial and temporal patterns}

Plots of the average number of species per sample and total faunal density versus sampling time are given in Figs, $3 \& 4$. The plots are arranged to allow direct visual comparisons between depths within a transect or between transects within a given depth range. Three-way ANOVAs were run on these data initially to test null hypotheses of no significant mean differences $(p \leq 0.05)$ due to the main effects of cruise, depth, transect location, and their interactions. Tests on both response variables resulted in Type I error probabilities below 0.05 ( $\mathrm{p}=$ near zero to 0.04 ) for each of the main effects and all 2 -way and 3-way interactions. Additional 2-way and 1-way ANOVA models with multiple-range tests were applied to portions of the data separately to provide a means for determining which levels of the main effects were significant and for interpreting the various interactions. Although detailed ANOVA out-

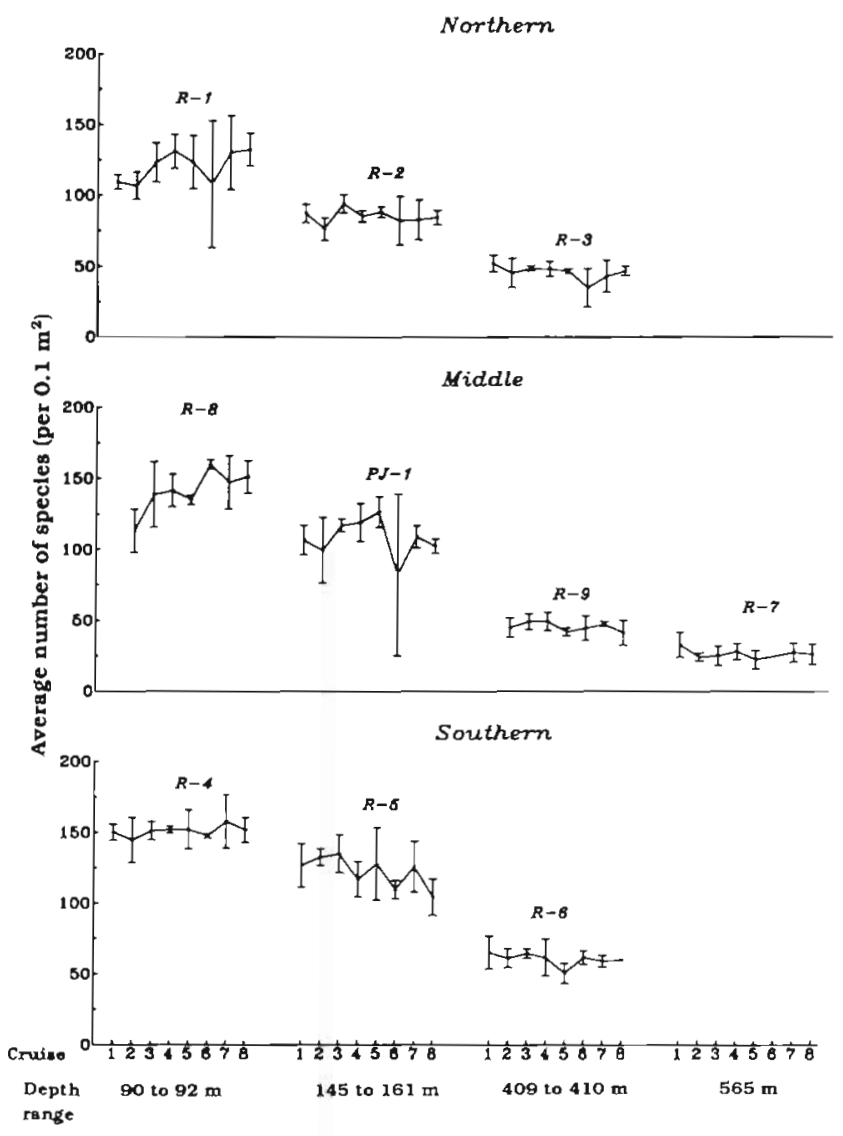

Fig. 3. Average number of macroinfaunal species per sample (based on average of 3 replicate $0.1^{2}$ samples) and $95 \%$ confidence intervals plotted against time (cruises). Cruises: $1=$ Oct $86 ; 2=\operatorname{Jan} 87 ; 3=$ May $87 ; 4=$ Oct $87 ; 5=\operatorname{Jan} 88$; $6=\operatorname{May} 88 ; 7=\operatorname{Oct} 88 ; 8=\operatorname{May} 89$ 


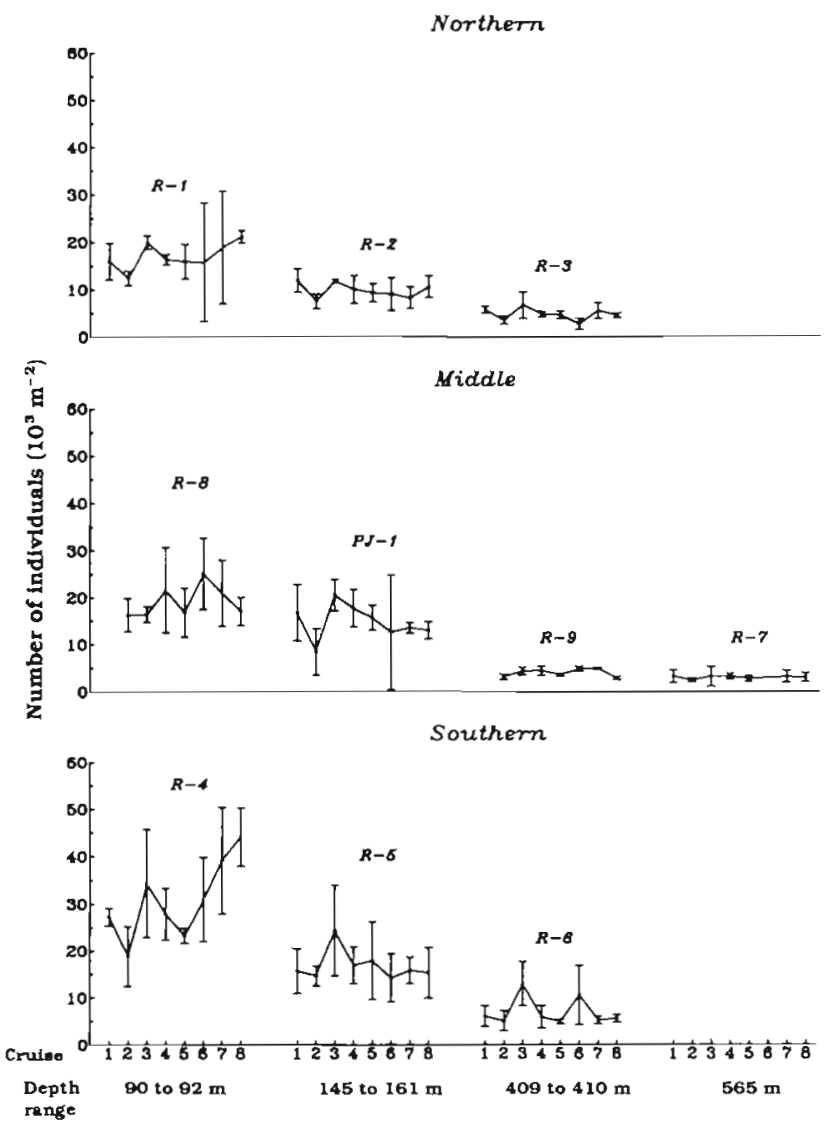

Fig. 4. Macroinfaunal densities (number of individuals $\times 10^{3}$ $\mathrm{m}^{-2}$, based on average of 3 replicate $0.1 \mathrm{~m}^{2}$ samples) and $95 \%$ confidence intervals plotted against time (cruises). Cruises: $1=\operatorname{Oct} 86 ; 2=\operatorname{Jan} 87 ; 3=\operatorname{May} 87 ; 4=\operatorname{Oct} 87 ; 5=\operatorname{Jan} 88$; $6=$ May $88 ; 7=$ Oct $88 ; 8=$ May 89

puts are not included in this paper, resulting Type I error probabilities are discussed to help interpret patterns of variation observed in the plots.

Numbers of species. Fig. 3 shows the general pattern of decreasing numbers of species with depth. Mean numbers of species (averaged over all replicates and cruises within a station) range from 121 to $1510.1 \mathrm{~m}^{-2}$ at stations along the $90 \mathrm{~m}$ isobath to $260.1 \mathrm{~m}^{-2}$ at Station R-7 $(565 \mathrm{~m})$. Differences between depths are highly significant ( $p=0.0001$ to 0.009 ) on all sampling occasions along all 3 transects. The effect of time, however, is interactive with a combination of both depth and transect location. For example, along the middle transect significant differences due to time occur only at the shallowest station $\mathrm{R}-8(\mathrm{p}=0.0004)$; in contrast, along the southern transect significant differences occur at the 2 deeper stations R-5 ( $p=0.006)$ and R-6 $(p=0.027)$. Along the northern transect there are no significant differences due to time at $p \leq 0.05$. The interaction of time and depth is significant along both the middle $(\mathrm{p}=0.036)$ and southern $(\mathrm{p}=0.0006)$ transects.
Transect location has a significant effect on species numbers within all 3 depth zones. There are significant differences between transects (at $p \leq 0.05$ ) on all cruises except $C 7(p=0.118)$ at $90 \mathrm{~m}_{\text {; }}$ on all cruises except $\mathrm{C} 6(\mathrm{p}=0.354)$ at 145 to $161 \mathrm{~m}$; and on all cruises at $410 \mathrm{~m}$. On several cruises, however, stations from the northern vs middle transects and from the middle vs southern transects do not differ significantly from one another at $p \leq 0.05$. Although overall community structure and composition appear to be relatively uniform among stations of similar depth (based on cluster analysisj, ANOVA results indicate significant mean differences in numbers of species along isobaths, especially for stations that are far apart. This source of variation seems to reflect the general trend of increasing numbers of species from the northern to the southern transect (Fig. 3, Tables 2 \& 3).

Density of total fauna. Fig. 4 reveals the general pattern of decreasing macrofaunal density with depth. Mean densities (averaged over all replicates and cruises within a station) range from 17100 to 30771 $\mathrm{m}^{-2}$ at stations along the $90 \mathrm{~m}$ isobath to $2964 \mathrm{~m}^{-2}$ at Station R-7 $(565 \mathrm{~m})$. Mean differences between depths are significant ( $p=0.0001$ to 0.023 ) on all cruises along all transects. In contrast, significant temporal differences (at $p \leq 0.05$ ) occur only at Stations $R-2(p=0.018)$ and $R-3(p=0.0008)$ along the northern transect, at Station R-9 ( $p=0.0001)$ along the middle transect, and at Station R-4 ( $\mathrm{p}=0.0001)$ along the southern transect. The interaction of time and depth is highly significant along the middle $(p=0.011)$ and southern $(p=0.0001)$ transects and relatively insignificant $(p=0.272)$ along the northern transect. Thus, as in the case for numbers of species, temporal variability in density is affected by a combination of depth and transect location.

Similar to the effect on numbers of species, the effect of transect location on density is significant within all 3 depth zones. There are significant differences between transects at $p \leq 0.05$ on all cruises except $C 6(p=0.120)$ at $90 \mathrm{~m}$; on all cruises except $\mathrm{C} 6(p=0.545)$ and $\mathrm{C} 8$ $(p=0.076)$ at 145 to $161 \mathrm{~m}$; and on all cruises except $\mathrm{C} 2$ $(p=0.063), C 4(p=0.228)$, and $C 7(p=0.621)$ at $410 \mathrm{~m}$. Thus variation within a depth stratum must be taken into account when interpreting bathymetric patterns over broad areas.

\section{Multiple discrimant analysis}

Mean values of other measured environmental variables for the 6 station groups defined by numerical classification of the macroinfaunal species data are given in Table 4. Multiple (canonical) discriminant analysis was performed to identify the variables that best account for the station groupings, as a means of 
Table 4 Untransformed mean values of abiotic environmental variables (D. Hardin, Kinnetic Laboratories, Inc., pers. comm.) for station groups defined by numerical classification of macroinfaunal species data. $\mathrm{DO}=$ dissolved oxygen, TOC = total organic carbon

\begin{tabular}{|c|c|c|c|c|c|c|c|c|c|}
\hline $\begin{array}{l}\text { Station } \\
\text { cluster } \\
\text { group }\end{array}$ & $\begin{array}{l}\text { Stations } \\
\text { included }\end{array}$ & $\begin{array}{c}\text { Depth } \\
\text { (m) }\end{array}$ & $\begin{array}{c}\text { Mean } \\
\text { grain } \\
\text { size }(\varnothing)\end{array}$ & $\begin{array}{l}\text { Sorting } \\
(\varnothing)\end{array}$ & $\begin{array}{l}\text { Percent } \\
\text { sand }\end{array}$ & $\begin{array}{l}\text { Percent } \\
\text { silt }\end{array}$ & $\begin{array}{l}\text { Percent } \\
\text { clay }\end{array}$ & $\begin{array}{c}\mathrm{DO} \\
\left.(\mathrm{ml} \mathrm{l})^{-1}\right)\end{array}$ & $\begin{array}{c}\mathrm{TOC} \\
(\%)\end{array}$ \\
\hline 1 & R1, R8, R4 & 91 & 4.3 & 1.3 & 24.4 & 67.4 & 8.1 & 3.1 & 0.63 \\
\hline $2 \mathrm{~A}$ & PJ1, R2 & 153 & 4.7 & 1.6 & 10.6 & 76.4 & 12.8 & 2.7 & 0.99 \\
\hline $2 \mathrm{~B}$ & RS & 154 & 4.0 & 1.4 & 53.3 & 41.0 & 5.0 & 2.7 & 0.52 \\
\hline $3 \mathrm{~A}$ & R3, R9 & 409 & 4.9 & 1.7 & 5.0 & 82.1 & 12.8 & 1.3 & 1.41 \\
\hline $3 B$ & R6 & 410 & 4.2 & 1.2 & 34.4 & 59.1 & 6.4 & 1.0 & 0.66 \\
\hline 4 & R7 & 565 & 5.0 & 2.5 & 4.0 & 64.3 & 31.6 & 0.6 & 2.55 \\
\hline
\end{tabular}

determining what environmental factors are important in structuring the macroinfaunal communities. A separate test to examine the possible influence of meiofaunal variables on macrofaunal distributions produced an insignificant second discriminant function, not interpretable graphically. Thus, subsequent discussion focuses on the 8 abiotic environmental variables shown in Table 4. Among-group differences based on these variables are highly significant ( $F$ statistics $=$

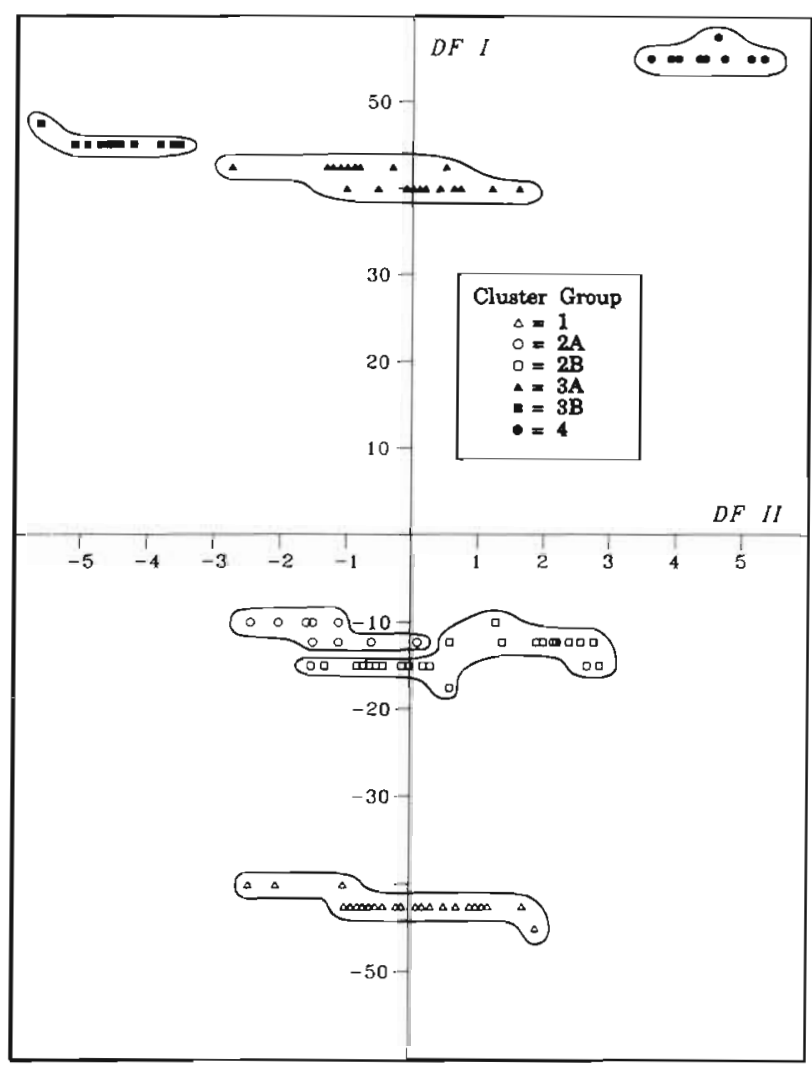

Fig. 5. Separation of station cluster groups on the first 2 discriminant functions (DF [ and II). Note that 33 observations are hidden
29 to $12179 ; \mathrm{df}=8,116)$ as are the first 2 discriminant functions (Function I: $F=124.4 \mathrm{df}=40,508$; Function II: $F=20.1, \mathrm{df}=28,423$ ). Fig. 5 shows the separation of the groups of stations on the first and second discriminant functions, which account for 99.56 and $0.28 \%$, respectively, of the among-group variance (cumulative percent $=99.84$ ). Because additional functions add little to the interpretation, evaluation of group separation is based on the interpretation of these 2 functions. The total structure coefficients (Table 5) aid in this interpretation by providing a measure of the relative importance of each variable in discriminating among the groups (see similar application by Weston 1988).

The 6 groups are separated on DF I largely as a result of differences in depth and near bottom levels of dissoived oxygen. Group 1 consists of the shallowest outer-shelf stations (mean depth $=91 \mathrm{~m}$ ) characterized by the highest levels of dissolved oxygen (mean = $3.1 \mathrm{ml} \mathrm{l}^{-1}$ ). Groups $2 \mathrm{~A}$ and $2 \mathrm{~B}$ represent upper-slope stations $(153 \mathrm{~m})$ with mean oxygen levels of $2.7 \mathrm{ml} \mathrm{l}^{-1}$. Groups 3A and 3B represent mid-slope stations (409 m) with mean oxygen levels of 1.0 to $1.3 \mathrm{ml} \mathrm{l}^{-1}$. Group 4 consists of the sea-valley station R-7, which has the greatest depth $(565 \mathrm{~m})$ and lowest mean oxygen level $\left(0.6 \mathrm{ml} \mathrm{l}^{-1}\right)$.

Table 5. Total structure coefficients (TSC) of abiotic environmental variables on the first 2 discriminant functions (DF). Coefficients of variables considered important on each function are underlined. $\mathrm{DO}=$ dissolved oxygen, $\mathrm{TOC}=$ total organic carbon

\begin{tabular}{|lrr|}
\hline Variable & \multicolumn{2}{c|}{ TSC } \\
\cline { 2 - 3 } & DF I & DF II \\
\hline Depth (m) & $\underline{0.998}$ & 0.057 \\
Grain size (phi) & 0.118 & 0.343 \\
Sorting (phi) & 0.591 & $\underline{0.736}$ \\
Percent sand & -0.407 & $-\underline{\underline{0.649}}$ \\
Percent silt & 0.010 & 0.269 \\
Percent clay & 0.376 & 0.437 \\
DO (ml 1 $\left.{ }^{-1}\right)$ & $-\underline{0.810}$ & -0.127 \\
TOC $(\%)$ & 0.617 & $\underline{0.677}$ \\
\hline
\end{tabular}


DF II reveals the influence of percent sand, sediment organic matter, and sediment sorting on the separation of Group 2B from Group 2A, and Group 3B from 3A. Group 2B consists of Station R-5, which has a depth and mean concentration of dissolved oxygen similar to those of Group 2A; however, the sediment of Station $\mathrm{R}-5$ has a much higher percentage of sand and lower amount of organic carbon in comparison to those of the more northern stations along the same isobath (PJ-1 and R-2). Similarly, Station R-6, which comprises Group 3B, has a depth and mean concentration of dissolved oxygen similar to those of Group 3A; however, the sediment at Station R-6 has a much higher percentage of sand and lower amount of organic matter in comparison to those of the more northern stations along the same isobath (R-3 and R-9). The sediment at Station R-6 also has a much lower sorting coefficient indicating a greater amount of particle sorting. Group 4 (Station R-7) is also separated on DFII from other deeper-water stations comprising Groups $3 \mathrm{~A}$ and $3 \mathrm{~B}$ and further exemplifies the influence of these same 3 sediment variables. The sediment at Station R-7 has the lowest percentage of sand, highest amount of sediment organic matter, and the highest sorting coefficient among all stations.

\section{DISCUSSION}

\section{Spatial patterns of species diversity and abundances}

This study reveals distinct patterns of decreasing macrofaunal abundances and diversity with increasing water depth. Similar patterns have been reported in other areas off the coast of southern California (Fauchald \& Jones 1978, SAIC 1986) and central and northern California (Lissner 1989). However, the pattern of species diversity is at variance with results of classic studies conducted in the western North Atlantic, which show that the diversity of a variety of macrofaunal taxa increases with depth from the shelf to upper-rise depths of about 2300 to $2800 \mathrm{~m}$ (Sanders 1968, Rex 1981) and then decreases again with increasing distance onto the abyssal plain (Rex 1981). Both the abundances and diversity of macrofauna have been shown to increase with depth across the shelf off New England (Neff et al. 1989) and in the Middle Atlantic Bight (Boesch 1979). Such differences demonstrate that efforts to predict faunal patterns in relation to depth gradients in the ocean must take into account a complexity of factors causing variation on local or regional scales.

In the present study, stations at depths less than $200 \mathrm{~m}$ are characterized by the highest macrofaunal densities ( 8983 to $28826 \mathrm{~m}^{-2}$ ), numbers of species
(85 to $1510.1 \mathrm{~m}^{-2}$ ), and species diversity $\left(H^{\prime}, 5.2\right.$ to 5.6 ). Other studies have shown much lower values for comparable depths along the California coast. SAIC (1986), for example, reports lower densities (800 to $6240 \mathrm{~m}^{-2}$ ), numbers of species (32 to $1100.1 \mathrm{~m}^{2}$ ), and species diversity $\left(H^{\prime}, 2.99\right.$ to 3.72$)$ for similar shelf and upper-slope depths throughout the southern Santa Maria Basin and western Santa Barbara Channel. Fauchald \& Jones (1978) report lower values (densities: $5366 \mathrm{~m}^{-2}$; numbers of species: $870.1 \mathrm{~m}^{-2}$; and $H^{\prime}: 2.6$ to 3.5) for stations at depths less than $200 \mathrm{~m}$ in the Southern California Bight. Lissner (1989) also reports lower values (densities: 5990 to $11350 \mathrm{~m}^{-2}$; numbers of species: 86 to $970.1 \mathrm{~m}^{-2}$; and $H^{\prime}:$ 1.6) for stations at depths of 100 to $200 \mathrm{~m}$ in basins along the central and northern California coast.

The high values of macrofaunal abundance and diversity encountered in the present study are comparable to those reported for Georges Bank (densities of 2500 to $55000 \mathrm{~m}^{-2}$ and $H^{\prime}$ values of 1.1 to 5.7 ; Neff et al. 1989) and for the North Sea in locations unaffected by oil-platform discharges (densities of 13000 to 20000 $\mathrm{m}^{-2}$ and $H^{\prime}$ values of 4.3 to 5.8 ; Kingston 1987). These locations are recognized as being among the most productive fishing areas in the world. The large numbers of species and individuals encountered in the present study suggest that the southern portion of the Santa Maria Basin also supports a highly diverse and abundant macroinfauna. Similarly, Montagna (in press) notes that densities of meiofauna are much higher in the southern Santa Maria Basin in comparison to other well-studied regions, such as the southeastern U.S. continental shelf (Coull et al. 1982), and are comparable to those found in the North Sea (McIntyre 1964, Faubel \& Hartwig 1983).

The high diversity of benthos in the region may be related to the fact that the southern Santa Maria Basin is at a zone of biotic transition between 2 zoogeographic provinces: the Oregonian province north of Point Conception and the California Province to the south (Valentine 1966). The macrofauna, for example, include possible endemic species and representatives from both the northern and southern provinces. High abundances could be related to the prominent upwelling events in the area, which contribute to new primary production (Dugdale \& Wilkerson 1989) and ultimately to increased supplies of organic material transported to the benthos. The spring upwelling season coincides with periodic peaks in the abundances of total macrofauna and some of the dominant species (e.g. Chloeia pinnata and Nephtys cornuta; plots not included) although the overall temporal patterns for these species are variable from year to year (see below). Silicate and nitrate concentrations are also generally higher in surface waters during 
spring when upwelling events are more common (Hyland et al. 1990).

The above macrofauna comparisons seem valid considering they are based on samples that were all processed with the same size sieves $(0.5 \mathrm{~mm})$. However, other general methodological differences (e.g. live-specimen vs preserved-specimen sieving; different groups of taxonomists) may account for the higher densities and species numbers found in this study relative to those reported by SAIC (1986) for overlapping sampling sites in the southern Santa Maria Basin portion of their study. Thus the apparently higher densities and diversity of benthic fauna in the present study area, relative to other regions along the California coast to the north or south, should be interpreted with some caution until additional comparisons can be made. Nonetheless, the present results still demonstrate that the study area supports an abundant and diverse benthic fauna comparable to other regions of known, high biological productivity.

\section{Temporal variability}

Results of ANOVA provide evidence of significant temporal variability in both abundances and numbers of species. Because stations were sampled randomly at each point in time, it is possible that spatial patchiness among replicates, which is pronounced particularly among the shallower stations (Figs. $3 \& 4$ ) is a source of the observed differences among sampling times. However, several lines of evidence suggest that these temporal fluctuations are the result of biological processes rather than sampling error For example, temporal changes in density during the first year of sampling form a pattern common among most stations (all but R-8 and R-9). This pattern consists of a low during the first winter (Jan 1987), a peak during the following spring (May 1987), and another low beginning in the second autumn (Oct 1987) and continuing through the second winter sampling (Jan 1988) (Fig. 4). This same within-year pattern is not repeated in its entirety at all stations in subsequent years. However, additional density peaks in May of 1988 or 1989 occur at several stations (R-4, R-8, R-1, R-2, R-6). Density lows during October also occur in subsequent years at 2 stations (R-2 in May 1989, R-6 in May 1988).

The occurrence of density peaks in May could very well represent a benthic response to increased sedimentation of phytodetritus, as a result of upwelling events which typically occur in the study area during the spring and summer (Kinney et al. 1990). Densities of one of the dominant polychaetes, Chloeia pinnata (plots not included), exhibited strong peaks during one or more of the May sampling periods at all stations.
These peaks usually resulted from large blooms of juveniles. For example, at Station R-6, C. pinnata increased from 63 to $7800 \mathrm{~m}^{-2}$ between January and May 1987, and from 380 to $6200 \mathrm{~m}^{-2}$ between January and May 1988. These blooms, represented mostly by smail juveniles, coincide with peaks in total faunal densities observed at this same station (Fig. 4). The polychaete Nephtys cornuta also exhibited occasional peaks in density during the spring upwelling period. Similarly, in the companion study of meiobenthic communities, Montagna (in press) suggests that increased meiofaunal densities in autumn 1987 could be a lagged benthic response to upwelling conditions. However, in both studies, distinct seasonal cycles are difficult to detect and are not repeated throughout all sampling years and stations.

\section{Relationships between macroinfaunal and other environmental variables}

Near-bottom dissolved oxygen, which decreases with depth, could be an important controlling factor in depth-related biological changes. Fig 6 illustrates the close correlation between oxygen and macroinfaunal densities. The decrease in oxygen with depth is attributable to the fact that the oxygen minimum zone impinges upon the continental slope off California at depths (500 to $700 \mathrm{~m}$; Emery 1960) that encompass our deepest station, R-7 $(565 \mathrm{~m})$. The dysaerobic levels of oxygen observed at Station R-7, which average about $0.6 \mathrm{ml} \mathrm{l}^{-1}$, approach values $\left(<0.15 \mathrm{ml} \mathrm{l}^{-1}\right)$ shown to be lethal to some benthic invertebrates under laboratory conditions (Theede 1973). Rhoads et al. (1971) also note that the diversity of benthic invertebrates in several oxygen-deficient marine basins drops markedly as oxygen falls below the range of 1.0 to $0.3 \mathrm{~mL} \mathrm{l}^{-1}$.

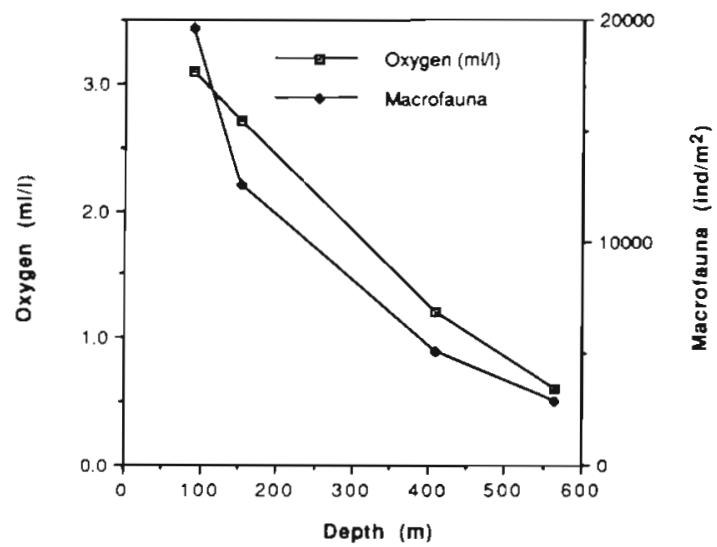

Fig. 6. Comparison of depth-related patterns in macroinfaunal densities and dissolved oxygen concentrations (bottom water) averaged over all sampling periods between Oct 1986 and Oct 1988 
Similar patterns of low macrobenthic abundances and reduced oxygen with depth have been noted in basins along a majority of the California coast (Thompson et al. 1985, Thompson \& Jones 1987, Lissner 1989, Cimberg \& Smith in press) as well as in other parts of the world, including the upwelling system off Peru (Rosenberg et al. 1983), the Black Sea (Bacescu 1963), and organically enriched Scandinavian fjords (Mirza \& Gray 1981, Gray et al. 1988\}

The percentage of sand, which is an important variable on the second discriminant function, may explain the observed patterns of higher abundances and numbers of species at the 2 southern stations R-5 and R-6 in comparison to stations of similar depth and oxygen concentrations to the north. A possible explanation for these patterns is that the higher percentages of sand at these stations offer a greater number of microhabitats for interstitial species to exist. The importance of the fine-sand fraction in structuring macrobenthic communities has been demonstrated on the continental shelf off the coast of Cape Hatteras (Weston 1988) and throughout the Middle Atlantic Bight (Boesch \& Bowen in press). As suggested by Weston (1988), higher percentages of sand relative to finer particles may also increase sediment permeability, allowing greater penetration of oxygen. This would be especially important at depths where oxygen is already limiting.

Sediment sorting and organic content are also important variables contributing to the separation of station groups, although their exact roles in controlling species numbers and abundances are harder to interpret. Gray (1974) suggests that poorly sorted sediments may support higher species diversity because of the presence of a wider variety of particle types for benthic organisms to utilize. However, in the present study, the greatest numbers of species were found at stations with sediments that had the highest sorting (least dispersion of particle sizes). Weston (1988) observed that the degree of sorting in sediments off the coast of Cape Hatteras is probably a reflection of the effect of currents on sediment mobility. Similarly, at sites in the present study that are less depositional (the shallower stations along the northern and middle transects and all stations along the southern transect), currents most likely remove the finer particles leaving a more uniform distribution of coarser particles. Thus sediment sorting in itself does not appear to play a major role in controlling macrobenthic community differences, although it serves as a useful indicator of these differences.

Several of the dominant species are carnivorous (e.g. Nephtys cornuta, Fauchald \& Jumars 1979; Harpiniopsis epistomata, Oakden 1984) and thus can feed upon other smaller metazoans and protozoans. How- ever, the majority of these species are deposit feeders, which meet their nutritional requirements from ingestion and absorption of sedimentary organic matter. Although there is a logical functional link between macrobenthic organisms and sediment organic matter as a food source, in this study low macroinfaunal abundances occurred at stations where TOC concentrations were high. Thus the benthic macrofauna of the region do not seem to be limited by low amounts of organic matter. To explain a similar trend along basin slopes in the Southern California Bight, Thompson \& Jones (1987) suggested that the low oxygen levels at deeper sites may limit the metabolism of the increased organic material also found at these depths. Another interpretation is that organic matter is simply a manifestation of particle size and, thus, both percent sand and TOC appear as variables that are important in discriminating between station groups. Because of the greater surface-to-volume ratio, it is commonly understood that finer particles have a proportionately greater organic content.

The present study indicates that spatial differences in the composition of macroinfaunal communities in the southern Santa Maria Basin are related foremost to depth in addition to gradients of sedimentary and other depth-associated physical variables. Low oxygen appears to be a primary controlling factor, although percent sand is also important and explains differences that segregate some stations of comparable depth and oxygen levels. While other variables, such as sediment sorting and organic content, are strong discriminators of faunal group differences, their role as controlling factors are harder to interpret, given the direction of their association with the macroinfaunal data. Other factors not measured in this study (e.g. variations in the flux and composition of detrital material or in the intensity of biological interactions such as predation and competition) might also be important in controlling these patterns.

Regardless of the source, the natural variations in these communities should be recognized in any subsequent efforts to monitor potential long-term impacts of offshore oil development. Moreover, we strongly urge that future research in the region include studies that contribute additional information on the importance of organism-oxygen relations, which could become a key consideration under drilling scenarios where the discharge of oil or organic-based muds lead to greater oxygen demands. We suggest that such research include a combination of field and manipulative laboratory experiments to determine the stability of the oxygen gradient, the effects of reduced oxygen on dominant benthic fauna independent of other environmental variables, and the mechanisms of low-oxygen tolerance. 
Acknowledgements. This study was funded by the US Department of Interior/Minerals Management Service (Pacific OCS Office, Los Angeles, California 90017) under Contract No 14-12-0001-30262 to Battelle Ocean Sciences. We express our sincere appreciation to Dr Gary Brewer, the MMS Project Technical Officer The following individuals provided assistance with sample sorting: Christie Robinson, Valerie Eikelmann, Elaine Byers, Heidi DeBra, Steve Mellenthien, Ned Borglin, David Carroll, Kathy Wakelee, Edrice Angry, and Patrick Hart. The long hours and skill provided by these individuals were invaluable. In addition to 2 of the authors (Sue Williams who worked on polychaetes, oligochaetes, platyhelminthes and echinoids, and Roy Kropp who worked on arthropods and molluscs), a number of taxonomic experts from various institutions participated in the identification and enumeration of species, and we are extremely grateful for their involvement. Assistance with polychaetes was provided by Leslie Harris, Eugene Ruff and James Blake; with molluscs, by Paul Scott and Jay Shrake; with arthropods, by Gary Gillingham, Jon Toal, Peter Slattery and Les Watling (cumaceans only); and with oligochaeles, by Russ Winchell. Treatment of remaining taxonomic groups was performed as follows: echiurans and sipunculids (Bruce Thompson) cnidarians (John Ljubenkov), nemerteans (Charles Phillips) holothuroids (Mary Bergen), and ophiuroids (Jim Laughlin) Participation of these individuals ensured a high level of taxonomic quality and intercalibration throughout the study. We thank Paul Montagna for providing data on meiofaunal variables and Dane Hardin for providing data on other abiotic environmental variables used in the multiple discriminant analysis. We also extend our appreciation to James Blake for his interpretative input during initial stages of the study, to Tom Gulbransen and John Hennessy for managing the data base, to Doug Coats for the production of computer-assisted graphics, and to Roger Green for statistical advice. Lastly, we thank Donna Good Higbee for typing the manuscript

\section{LITERATURE CITED}

Bacescu, M. (1963). Contribution à la biocoenologie de la Mer Noire. L'étage périozoique et le faciès dreissenifère. leurs charactéristiques. Proc. Verg. Réun. C.I.E.S.M. 17: $107-122$

Boesch, D. F. (1977). Application of numerical classification in ecological investigations of water pollution. EPA Grant No. R803599-01-1, ROAP/TASK No. 21 BEI., Corvallis Environmental Research Laboratory, Newport, Oregon

Boesch, D. F. (1979). Benthic ecological studies. macrobenthos. Chapter 6, Middle Atlantic Outer Continental Shelf Environmental Studies, Vol. IIB, Chemical and biological benchmark studies. Report to U.S. Dept of Interior, Bur Land Management (now Minerals Management Service), Herndon, VA. Contract no. AA550-CT6-62

Bray, J. R., Curtis, J. T (1957). An ordination of the upland forest communities of southern Wisconsin. Ecol. Monogr. 27: $320-349$

Brink, K. H., Stuart, D.W., Vanleer, J, C. (1984). Observations of the coastal upwelling region near $34^{\circ} 30^{\circ} \mathrm{N}$ off California: spring 1981. J. phys. Oceanogr. 14: 378-391

Cimberg, R. L., Smith, R. W. (in press). Distribution of benthic communities relative to oxygen levels near Pt. Conception, California. 3rd California Islands Symposium, Santa Barbara Natural History Museum, Santa Barbara, CA
Coull, B. C., Zo, Z., Tietjen, J. H., Williams, B. S. (1982). Meiofauna of the southeastern United States contınental shelf. Bull. mar. Sci. 32: 139-150

Dames \& Moore (1983). Site-specific marine biological survey, Chevron Platform Hermosa project, western Santa Barbara Channel. Report submitted to Chevron USA, Inc. Environmental Affairs, PO Box 1392, Bakersfield, CA 93302

Dugdale, R. C., Wilkerson F. P. (1989). New production in the upwelling center at Point Conception, California: temporal and spatial patterns. Deep Sea Res. 36(7): 955-1007

Emery, K. O. (1960). The sea off southern California. John Wiley and Sons, New York

Engineering-Science (1984). Marine biological survey for Platform Hidalgo site and corresponding pipeline route. Report submitted to Chevron USA, Inc., Environmental Affairs, PO Box 1392, Bakersfield, CA 93302

Faubel, A., Hartwig, E. (1983). On the ecology of the benthos of sublittoral sediments, Fladen Ground, North Sea I. Meiofauna standing stock and estimation of production. 'Meteor' Forschergebn. 36: 35-48

Fauchald, K., Jones, G. F. (1978). Varnation in community structure uf shelf, slope and basin macrofaunal communities of the Southern California Bight. Chapter 19, Year II benthic study. Report submitted by Science Applications, Inc. to Bureau of Land Management, Pacific OCS Office, Los Angeles, CA under Contract No. AA551-CT6-40

Fauchald, K., Jumars, P. A. (1979). The diet of worms: a study of polychaete feeding guilds. Oceanogr mar. Biol. A. Rev. 17. $193-284$

Gray, J S. (1974). Animal-sediment relationships. Oceanogr. mar. Biol. A Rev. 12: 223-261

Gray, J. S., Aschan, M., Carr, M. R., Clarke, K. R., Green, R. H., Pearson, T H., Rosenberg, R., Warwick, R. M. (1988). Analysis of community attributes of the benthic macrofauna of Frierfjord/Langesundfjord and in a mesocosm experiment. Mar. Ecol. Prog. Ser. 46: 151-165

Green, R. H., Vascotto, G. L. (1978). A method for the analysis of environmental factors controlling patterns of species composition in aquatic communities. Wat. Res. 12: $583-590$

Hyland, J., Hardin, D., Crecelius, E., Drake, D., Montagna, P., Steinhauer, M. (1990). Monitoring long-term effects of offshore oil and gas development along the southern California outer continental shelf and slope: background environmental conditions in the Santa Maria Basin. Oil and Chem. Pollut 6: 195-240

Jones, G. F. (1969). The benthic macrofauna of the mainland shelf of southern California. Allan Hancock Monogr. mar Biol. $4: 1-219$

Kingston, P. F. (1987). Field effects of platform discharges on benthic macrofauna. Phil. Trans. R. Soc. (Ser B) 316 $545-565$

Kinney, P., Wilde, P., Beard, D., Coats, D., Bernstein, R. (1990) Hydrology. Chapter 3, California OCS Phase II Monitoring Program, Year Three Annual Report. Report to the U.S Department of Interior, Minerals Management Service, Pacific OCS Region, Los Angeles, CA. Contract No. 14-12 0001-30262, MMS 90-0055

Lissner, A. (ed.) (1989). Benthic reconnaissance of central and northern California OCS areas. Final report, Vols. I and II Report prepared for U.S. Department of Interior, Minerals Management Service, Pacific OCS Region, Los Angeles CA. Contract No. 14-12-0001-30388. OCS Study MMS 89-0039, 89-0040

McClelland Engineers (1985). Site-specific marine biological survey. San Miquel Project, Santa Maria Basin, CA 
McIntyre, A. D. (1964). Meiobenthos of sub-littoral muds. J. mar biol. Ass. U.K 44:665-674

Mirza, F. B., Gray, J. S. (1981). The fauna of benthic sediments from the organically enriched Oslofjord, Norway. J. exp. mar. Biol. Ecol. 54: 181-287

Montagna, P. A. (in press). Meiobenthic communities of the Santa Maria Basin on the California continental shelf. Contin. Shelf Res. 11.

Neff, J. M., Bothner, M. H., Maciolek, N. J., Grassle, J. F. (1989). Impacts of exploratory drilling for oil and gas on the benthic environment of Georges Bank. Mar environ. Res. $27 \cdot 77-114$

Nekton, Inc. (1983). Site-specific faunal characterization survey for Platform Harvest, OCS Lease P-0315, Point Conception, California. Report submitted to Texaco USA, Exploration and Production,. Inc., Environmental Health and Safety, 8055 E. Tufts Ave., Denver, CO 80237

Nekton, lnc. (1984). Supplemental survey program faunal characterization survey for Platform Harvest, OCS Lease P-0315. Report submitted to Texaco USA, Exploration and Production,. Inc., Environmental Health and Safety, 8055 E. Tufts Ave., Denver, CO 80237

Oakden, J. M. (1984). Feeding and substrate preference in five species of phoxocephalid amphipods from central California. J. Crustacean Biol. 4(2): 233-247

Pielou, E.C. (1966). Species-diversity and pattern-diversity in the study of ecological succession. J. theor. Biol. 10: $370-383$

Rex, M. A. (1981). Community structure in the deep-sea benthos. A. Rev. Ecol. Syst. 12: 331-353

Rhoads, D. C., Morse, J. W. (1971). Evolutionary and ecological significance of oxygen-deficient marine basins. Lethaia 4: 413-428

Rintoul, B. (1985). Fifteen platforms planned off California. Offshore 45(1): $60-61$
Rosenberg, R., Arntz, W. E., Deflores, E. C., Flores, L. A., Carbajal, G., Finger, I., Tarazona, J. (1983). Benthos bromass and oxygen deficiency in the upwelling system off Peru. J. mar. Res. 41. 263-279

Sanders, H. L. (1968). Marıne benthic diversity: a comparatıve study. Am. Nat. 102: 243-282

SAS Institute, Inc. (1985). SAS users guide: statistics, version 5 edn. SAS Institute, Inc., Cary, NC

Science Applications International Corporation (SAJC). (1986). Assessment of long-term changes in biological communities in the Santa Maria Basin and western. Santa Barbara Channel - Phase 1. Final report (two volumes) submitted to U. S. Minerals Management Service, Pacific OCS Region, Los Angeles, CA, Contract No. 14-12-000130032

Shannon, C. E., Weaver, W (1949). The mathematical theory of communication. Univ. of Illinois Press, Urbana

Sneath, P. H. A., Sokal, R. R. (1973). Numerical taxonomy. The principles and practice of numerical classification. Freeman, San Francisco

Theede, H. (1973). Comparative studies on the influence of oxygen deficiency and hydrogen sulfide on marine bottom invertebrates. Neth. J. Sea. Res. 7: 244-252

Thompson, B. E., Jones, G. F. (1987). Benthic macrofaunal assemblages of slope habitats in the southern California borderland. Allan Hancock Foundation, N. S. 6: 1-21

Thompson, J. B., Mullins, H. T., Newton, C. R., Vercoutere, T L. (1985). Alternative biofacies model for dysaerobic communities. Lethaia 18: 167-179

Valentine, J. W. (1966). Numerical analysıs of marine molluscan ranges on the extratropical northeastern Pacific shelf. Limnol. Oceanogr. 11: 198-211

Weston, D. P. (1988). Macrobenthos-sediment relationships on the continental shelf off Cape Hatteras, North Carolina. Contin. Shelf Res. 8(3): 267-286

Manuscript first received: December 12, 1990

Revised version accepted: October 15, 1991 